\title{
Comparative Study on Adolescent Behavior Delinquency at the Institute of Islamic Education Ponorogo
}

\author{
Syarifan Nurjan ${ }^{1}$, Heru Kurnianto Tjahjono ${ }^{2}$, and Muhammad Nurul Yamin ${ }^{3}$ \\ Program Islamic Educational Psychology, Universitas Muhammadiyah Yogyakarta, \\ Indonesia ${ }^{1,2,3}$ \\ \{syarifanflo@yahoo.com ${ }^{1}$, heruutilitas@yahoo.com ${ }^{2}$, moehyamien@yahoo.com ${ }^{3}$ \}
}

\begin{abstract}
This study uses analysis test Structural Equation Model (SEM) with a comparative study on the behavior of delinquency adolescents is influenced by internal juvenile and environmental factors with psychosocial mediation control, who suspected that delinquency which is a symptom of illness socially in adolescents resulting social neglect. The population of this study was 1354 students of SMA Muhammadiyah I: 568 students; MA Maarif Al-Mukarrom: 323; MA Arrisalah: 261; and MA Darul Istiqomah: 202. The sample of this study were 224 students. Based on the research findings comparative study on adolescent delinquency who mediated psychosocial control in the Institute of Islamic Education Ponorogo that: 1) the environment and internal juvenile to psychological power has a direct influence positive, 2) psychosocial control, environmental, and internal minor on behavior delinquency has a direct influence positive, except in internal juvenile have a direct influence negative in MA Arrisalah, MA Al-Mukarrom and MA Darul Istiqomah, and psychosocial control have a direct influence negative in SMA Muhammadiyah I and in MA Darul Istiqomah, and 3) the environment mediated by psychological power has an indirect adverse effect in SMA Muhammadiyah I and MA Darul Istiqomah.
\end{abstract}

Keywords: Comparative Studies, Institute of Islamic Education, Behavioral Delinquency

\section{Introduction}

Adolescence involves a process that reaches an important period in one's life, posing so many challenges, such as changes from physical, biological, psychological, and social changes that require adolescents to cope with and overcome the challenges of change with psychological, emotional, and behavioral [1], [2].

Adolescence is a time of change, a time when adolescents face new experiences. In childhood, most adolescents live in a protected, organized environment where the parent or adult who is concerned is the one who is in control. During the adolescent stage, adolescents tend to be less dependent on family protection and stepping into situations they have never met. The various environments in motion present new situations and events[3]-[5].

General problems of adolescent in school based on information with interview technique and focus group discussion by Herien Puspitawati[6] from various source of headmaster or coach get description of delinquent adolescent include lack of discipline of student which is 
reflected from often late student entering school, school uniforms, breaking school rules like smoking in the neighborhood or out of school and often 'hanging around' outside the school fence so late to class. The lack of student motivation to learn reflects the rarity of students reading the literature, the insecurity of students at home and school, and the difficulty of students getting public transportation to leave and go home.

According to developmental psychologists Papalia et al. [7], Jhon W. Santrock [8], Messina \& Messina [9], Gilliom et al. [8]), there are several reasons that cause adolescents to engage in delinquency behaviors, including (1) immature personality, (2) genetics, (3) unstable family living conditions not harmonious.

The symptoms of delinquency as described above are almost difficult to find in Islamic educational institutions. Islamic educational institutions, in this case, are pesantren, educational institutions under the organization of Muhammadiyah and NahdhatulUlama 'and other mass organizations. This can be attributed to the conclusion of Nata [10] which states that teenagers living in Islamic educational institutions including pesantren are more able to understand, live, and practice religion well. Also, the adolescents who live in the pesantren can read the Qur'an well, understand, and able to implement the teachings of worship well, living the values of religion and noble character.

But in reality, as the expression of Aan FauziRifa'i[11] in his research that life in pesantren/boarding schools obtained violation of santri like smoking, dating or courtship, staying outside the dorm, theft, and research RentiYasmar[12] that the santri mischief in the form of ditching, Late arriving at school, smoking, fighting, and interviewing results (along with Syamsul Hadi Untung [13] in Pondok Modern Gontor Ponorogo illustrates various disciplinary offenses, namely in 2011 in the form of minor offenses 34,111, 351 and heavy 22, Lighter 43,157, medium 1138 and weight 41 and year 2013 in the form of mild violation 39,100 , medium 450 and weight 52 .

Ponorogo regency has several criteria of Islamic education institution at junior and senior high school level, which is managed by Muhammadiyah organization as many as 24 institutions, NahdhatulUlama 'as many as 13 institutions, and in the form of pesantren; With the criteria of modern pesantren('ashriyah) as many as 18 institutions, traditional (salafi) as many as 9 institutions, and a combination of modern and traditional as many as 33 institutions [14].

Thus, adolescent life cannot be separated from the life of the surrounding community. In Islamic Educational Institution perform various psychosocial control of adolescent in the form of discipline approach, guidance and counseling approach, santri character development [15], development of social interaction pattern of kyai and santri[16], [17] and as Hirschi's selfcontrol theory on adolescent delinquency behavior is attributable to routine activity [18].

This study aims to the comparative study of the tendency of adolescent delinquency behavior in Islamic Education Institution in Ponorogo Regency. This analysis was taken to obtain similarities and differences in the tendency of adolescent delinquency behavior in four institutions, namely SMA Muhammadiyah I, MA Ma'arif Al-Mukarrom, MA Arrisalah Pesantren, and MA Pesantren Darul Istiqomah. 


\section{Literature review}

\subsection{Religiosity}

\subsubsection{Understanding Religiosity}

The religiosity of the Latin origin of religion, religare which means to collect, read, and also derives from the word Religare meaning binding, or in the Indonesian language is equivalent to the notion of religion that contains rules and ways of dedicating to God collected in the scriptures that must be understood and have the nature of binding to humans, because religion binds man with God. The word religion has several meanings both in terms of language and terms.

According to Jalaluddin defines religiosity is a state that exists in a person who encourages him to behave by the level of his devotion to religion. Furthermore, Skinner describes religious attitudes as expressions of how humans with conditioning the role of learning to live in a world ruled by the law of reward and punishment. Religious feelings are feelings related to God or the Almighty, among others, amazed, amazed, believed, convinced of faith, trustworthiness, resigned self, humble dependence on the Ilahi, feeling small self, the consciousness of sin and others.

\subsubsection{Dimension of Religiosity}

Religion or religiosity is manifested in all sides of human life. Religious activity is not only happening when one performs another activity that is driven by supernatural powers. It is not just about invisible activity and happening in a person's heart. Therefore one's diversity will cover many dimensions. The dimensions in religiosity or religiosity according to Glock and Stark are the following dimensions of belief, the dimensions of religious practice, the dimensions of experience, the dimensions of knowledge, and the dimensions of practice or consequence.

\subsection{Adolescent Delinquency Behavior}

\subsubsection{Understanding Adolescent}

Adolescence is a period of transition from childhood to adulthood. At this time the individual undergoes various changes, both physical and psychic. The apparent change is a physical change, in which the body develops rapidly to achieve adult body shape accompanied by the development of reproductive capacity [19], [20].

Adolescence is known as one of the periods in the human life span that has some uniqueness of its own. The uniqueness is derived from the position of adolescence as a transitional period between childhood and adulthood [21], [22], with physical changes, emotional change, Cognitive change [22] that adolescence is someone who in terms of chronological age is in the age range 12-21 years, who are undergoing biological, cognitive and social transitions, and are experiencing psychosocial development in the form of identity, autonomy, intimacy, sexuality, and achievement. 


\subsubsection{Theory of Adolescent Behavior}

Behavior as a reaction that can be both simple and complex in adolescents does not arise by itself, but as a result of stimuli received by the individual concerned both external and internal stimuli. The interesting behavioral characteristics of adolescent behavior is its differential nature. That is, a stimulus can lead to more than one different response and several different stimuli may generate a similar response behavioral relationship model that says behavior (B) is a function of individual characteristics $(P)$ and the environment $(E)$, ie $B=f(P$, E) $[23]$.

Skinner's Behaviorism emphasizes the scientific study of observed behavioral responses and reflected-reflected environments. In behavior according to B.F. Skinner [24] that mind, consciousness or unconsciousness, is not needed to explain behavior and development. The social cognitive theory states that behavior, environment, and cognition are important factors in development. Albert Bandura [25] is the architect of the contemporary version of the theory of social cognition, originally by Mischel [8] named cognitive, social learning theory.

Bandura states that behavioral, environmental, and personal/cognitive factors, such as belief, planning, and thinking, can interact on a reciprocal basis. Thus, in Bandura's view, the environment can affect one's behavior (according to Skinner's view), which includes selfefficacy, self-identity, and self-control.

\subsubsection{Adolescent Delinquency Theory}

Adolescents are referred to as Juvenile from Latin juveniles, meaning adolescent, characteristic traits in adolescent, traits typical in the adolescent period, while delinquent from the Latin "delinquere" Which means to ignore, expanded to evil, mischievous, anti-social, criminal, rule-breakers, noisemakers, vandals, terrorists, malpractors, etc. [26]. The term Juvenile delinquency or malicious behavior is a socially sick (pathological) symptom of adolescence caused by a form of social neglect, so they develop a form of perverse behavior [22].

Factors of juvenile delinquency according to Santrock [8] are identity, self-control, age [38], gender, expectations for education and values at school [26], Family processes [8], peer influences [8], socioeconomic classes, and the quality of the environment around the residence.

\subsection{Psychosocial Control Theory}

\subsubsection{Social Ties as Delinquency Behavior Factors}

Indonesia is known as a transitional society or modernizing society. Such societies differ from tradition-oriented societies and modern societies. The state of transitional society by Emile Durkheim [27] is said to bring individual members of society to anomie state is normalesness, that is a social system in the form of no guidance or guidance for behavior. Anomie or ambivalent conditions and ambiguous [28], this, of course, applies not only to members of the adult community but also to adolescents.

The need for social ties as school environments run by religious organizations, in the form of pesantren, boarding schools or other forms, so that the stronger social ties in the youth environment, further diminish the forms of delinquency, with various norms, rules, and the Islamic personality. 


\subsubsection{The Social Control Theory of Travis Hirchi}

The theory of social control departs from the assumption or assumption that individuals in the same society, being "good" or "bad." A good-evil person completely depends on strong social ties with his society [26]. Thus, according to this understanding, something to look for clarity is obedience to the norm and the factors that cause a person to obey or obey the norms of society. Hirschi [29] classification of elements of social bonding into four, namely (a) attachment, (b) commitment, (c) involvement, (d) beliefs.

\section{Method}

This study uses the Structural Equation Model (SEM) test [30], a model also called a covariance structure model to test empirical models in explaining variants and correlations between a set of variables that are observed in a causal system of unobserved factors and to determine the effects of both endogenous and exogenous latent variables directly or indirectly.

This type of research is a comparative study, where the research will be focused on the analysis to compare a research object between different subject and measurement model in the same period. The object of research is taken from four Islamic education institutions in Ponorogoregency Academic year 2016/2017.

Several variables are the independent variable in the form of adolescent internal, family environment, school environment, neighboring environment, and media, mediator variable in the form of psychosocial control from the family environment, school environment, media, and the dependent variable of teen delinquency behavior.

The measuring tool used in this study was a psychological scale consisting of self-control scale measured using self-control scale instrument developed by Hirschi [29], consisting of 24 items of questions, including aspects of sudden acting, instantaneous decision, risk-seeking ability, physical behavior, selfishness, and patience.

The scales of self-identity of Marcia [8] include the identity of the adolescent identity deprivation, identity foreclosure, identity moratorium, and identity achievement. The family environment scale is religious and spirituality of Al-Attas[49], i.e. self, body, matter outside of human self, school environment is ta'dib as religiosity of Amatullah Armstrong [31], ie education of etiquette in truth, education of manners in devotion, education of manners in Islamic law, education of manners in friendship, peer environment in the form of religiosity of Gloe and Stark [32] that is ideology, ritualistic, experiential, intellectual and kruseksuensial and media in the form of media intensity from Tubbs \& Moss [33] that is communication frequency and duration of communicate. Psychosocial control scale from Hirschi [18] is attachment, commitment, involvement, and beliefs and the tendency of delinquency adolescent behavior from Will Kalkhoff [54], that is in the form of violating behavior, dangerous behavior, impacting the behavior of the material victim, and behavior impact of the physical victim.

The population in this study were 1354 students from grade 1 and class 2 from SMA Muhammadiyah, MA Ma'arif, MA Pesantren Modern and traditional Pesantren MA [34]. Thus the total sample size of the study population was 225 students or $15 \%$ of the population. 


\section{Result and discussion}

\subsection{Results}

\subsubsection{Madrasah Aliyah Pondok Modern Arrisalah}

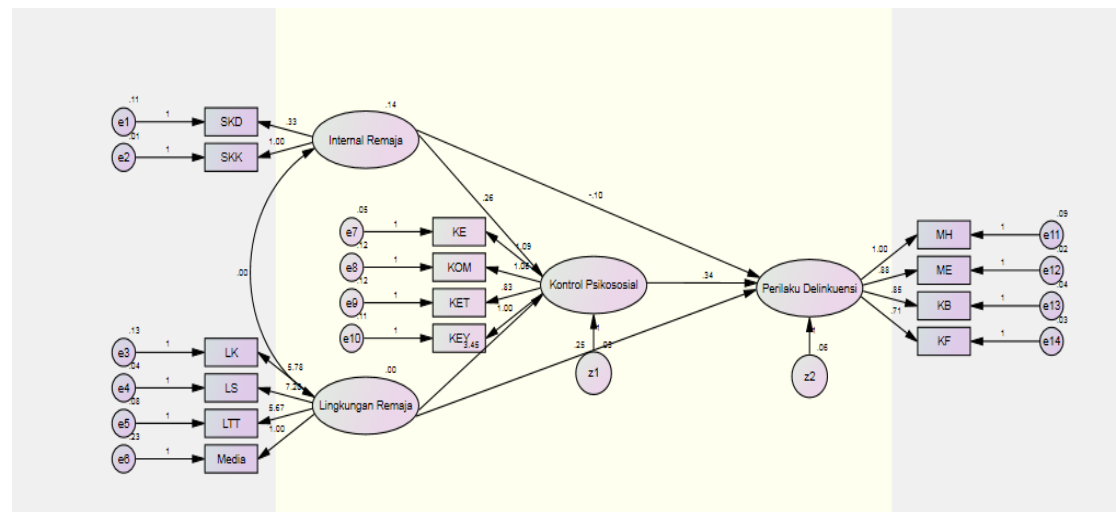

Figure 1. SEM Analysis in MA Arrisalah

Conformity testing of research model is used to test how the goodness of fit level of the research model. Based on the test results presented above, it is known from the 12 existing criteria, 8 of which are in fit condition, and 3 of them are stated not marginal fit and the remaining one is not fit. With this result, it can be said that the research model has a goodness of fit level.

Hypothesis testing is based on data processing research by using SEM analysis, by analyzing regression value which is shown Regression Weights Structural Equation Modeling Analysis. Testing this hypothesis is by analyzing the Critical Ratio (CR) value and Probability (P) value of the data if compared to the required statistical limitation, that is above 1.96 for CR value and below 0.05 for $P$ value.

Based on the above results obtained the significant of the internal influence of adolescents against psychosocial control. This hypothesis in this research is the influence of adolescent internal to control psychosocial. Based on the data processing is known that the value of CR in the table above is $2.575 \mathrm{P}$ value of 0.010 . The results of these two values provide information that there is an internal influence of adolescents on psychosocial control since it meets the preconditions where the CR value is above 1.96 and meets the $\mathrm{P}$ value below 0.05 , it can be said the hypothesis (H1) is accepted. While the other hypothesis is not fulfilled because it does not meet the prerequisite where the CR value above 1.96 and meet the value of $\mathrm{P}$ under 0.05 .

\subsubsection{Madrasah Aliyah Ma'arif Al-Mukarrom}

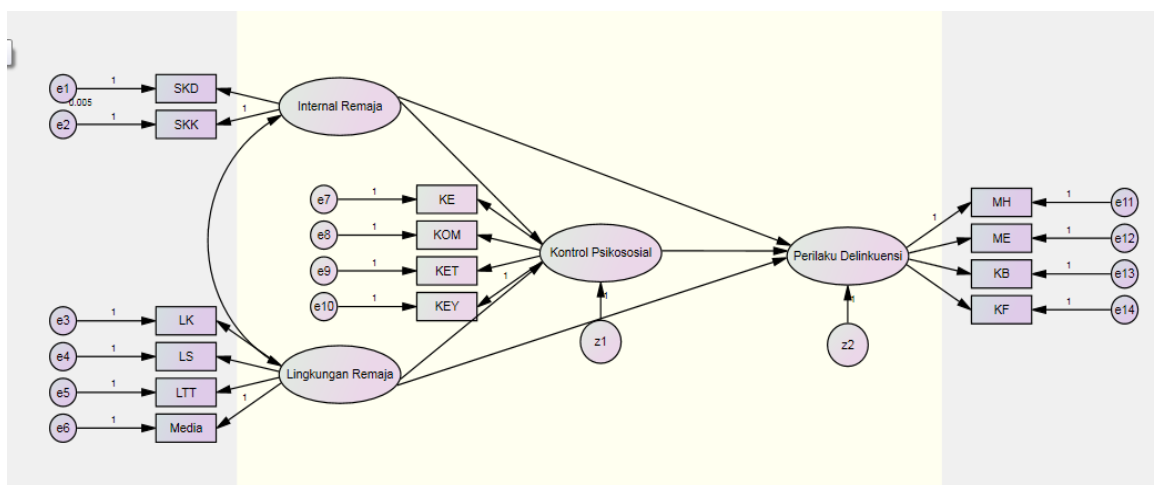


Figure 2. SEM value of Madrasah Aliyah Ma'arif Al-Mukarrom

Conformity testing of research model is used to test how the goodness of fit level of the research model. Based on the test results that have been presented, it is known from the 12 existing criteria, 3 of which are on the marginal fit and nine the rest is not fit. With this result as a whole, it is said that the research model has a goodness of fit level is less good. Based on the results obtained that only two significant hypotheses are:

- The influence of adolescent's internal to psychosocial control is 2,182 $\mathrm{P}$ value equal to 0,029 . The results of these two values provide information that there is an internal influence of adolescents on psychosocial control because it meets the preconditions where the CR value is above 1.96 and meets the $\mathrm{P}$ value below 0.05 . Thus hypothesis 1 (H1) is accepted.

- The existence of the internal environmental influence of adolescent toward delinquency behavior is $2,310 \mathrm{P}$ value equal to 0,021 . The results of these two values provide information that there is an influence of the adolescent's internal environment on delinquency behavior, since it satisfies the precondition where the CR value is above 1.96 and satisfies the $\mathrm{P}$ value below 0.05 . Hence it can be said that hypothesis 2 (H2) be accepted.

As for the other hypothesis is not met because it does not meet the prerequisites where the CR value above 1.96 and meet the value of $P$ under 0.05 .

\subsubsection{SMA Muhammadiyah 1 (SMA MUHIPO)}

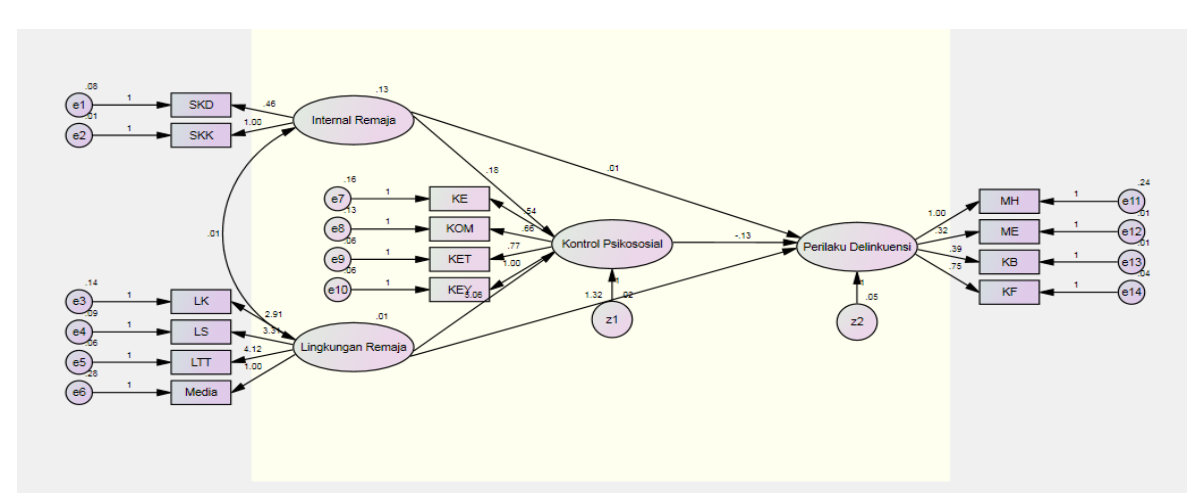

Figure 3. SEM Analysis of SMA Muhammadiyah 1

Conformity testing of research model is used to test how the goodness of fit level of the research model. Based on the test results presented above, it is known from the 12 existing criteria, 4 of which are on marginal fit and the remaining eight are not fit. With this result then overall can be said that the research model has the goodness of fit level less good. Based on the above results obtained that there is no significant hypothesis. This is because it does not meet the prerequisites at which the $\mathrm{CR}$ value is above 1.96 and satisfies the $\mathrm{P}$ value below 0.05 . 


\subsubsection{MA Darul Istiqomah}

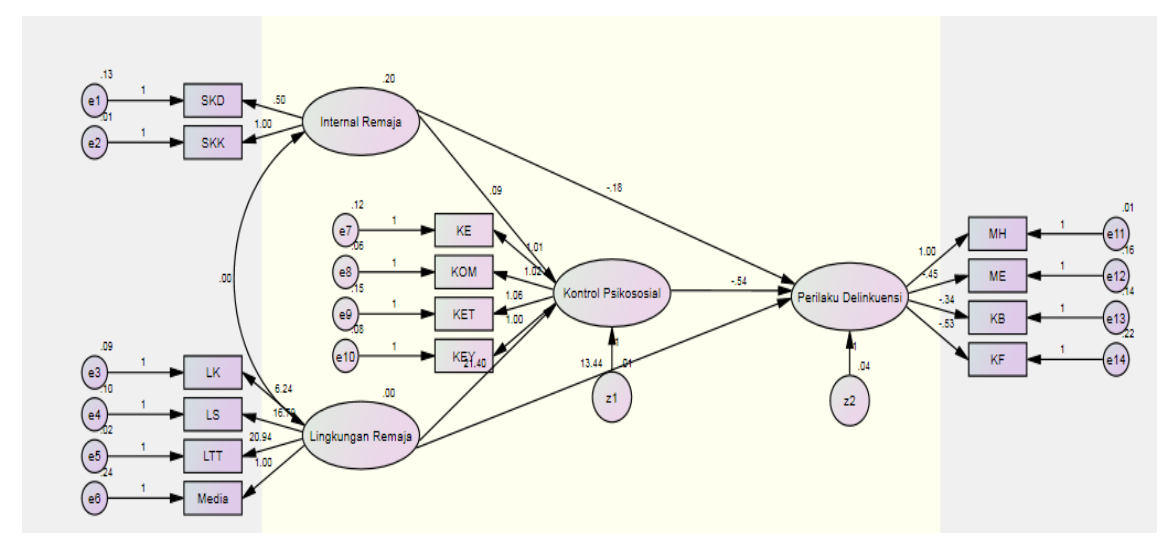

Figure 4. Analysis of SEM MA Darul Istiqomah

Conformity testing of research model is used to test how the goodness of fit level of the research model. Based on the test results presented above, it is known from the 12 criteria that exist, 11 of them declared not fit. With this result then overall can be said that research model has the goodness of fit level less good.

Based on the above table it is found that there is no significant hypothesis because it does not meet the requirement that $\mathrm{CR}$ value above 1,96 and meet $\mathrm{P}$ value below 0,05 .

\subsection{Direct Influence Analysis and Indirect Influence}

\subsubsection{Direct Effect Analysis}

\subsubsection{MA Pondok Modern Arrisalah}

- The enormous influence of teenagers environment on psychosocial control is 0.610 (61\%), and the magnitude of direct influence of adolescent's internal to psychosocial control by $0,294(29,4 \%)$.

- The influence of the psychosocial control on the behavior of delinquency of 0.438 (43.8\%) gives a positive influence, while the teenager environment contributes to 0.056 (5.6\%) gives positive and internal influence of adolescent toward the behavior of Delinquency $0,142(14,2 \%)$ give a negative effect.

\subsubsection{MA Ma'arif Al-Mukarrom}

- The direct influence of teenagers environment on psychosocial control is $0.715(71.5 \%)$, and the magnitude of the direct influence of adolescent's internal to psychosocial control by $0,215(21,5 \%)$.

- The influence of psychosocial control on the behavior of delinquency of $0.425(42.5 \%)$ gives a positive influence, while the youth environment contributes to $0.011(1.1 \%)$ gives positive and internal influence of adolescent toward the behavior of delinquency equal to $0,310(31 \%)$ gives influence negatively. 


\subsubsection{SMA Muhammadiyah 1 Ponorogo}

- The direct influence of teenagers environment on psychosocial control is $0.895(89.5 \%)$. and the direct internal influence of adolescent to psychosocial control is $0,134(13,4 \%)$.

- The influence of psychosocial control on the behavior of delinquency $0,264(26,4 \%)$ gives negative influence, while teenage environment gives a contribution to 0,494 $(49,4 \%)$ give positive influence and internal of adolescent to the behavior of delinquency equal to 0,010 (1\%) give influence positively.

\subsubsection{MA Darul Istiqomah}

- The direct influence of teenagers environment on psychosocial control is $0.966(96.6 \%)$. and the direct internal influence of adolescent to psychosocial control by $0,092(9,2 \%)$.

- The influence of psychosocial control on the behavior of delinquency is $1.076(107,6 \%)$ giving negative influence, while the adolescent environment contribute to 1,205 $(120,5 \%)$ give positive influence and internal of adolescent to the behavior of delinquency equal to $0,353(35,3 \%)$ give a negative effect

\subsubsection{Indirect Effect Analysis}

\subsubsection{Pondok Modern Arrisalah}

- The amount of indirect environmental influence of adolescent toward the behavior of delinquency because of the psychosocial control equal to $0,267(26,7 \%)$

- The amount of indirect influence of adolescent's internal to the behavior of delinquency because of the psychosocial control equal to $0,129(12,9 \%)$

\subsubsection{MA Ma'arif Al-Mukarrom}

- The amount of indirect environmental influence of adolescent toward the behavior of delinquency because of the psychosocial control equal to $0,304(30,4 \%)$.

- The amount of indirect influence of adolescent toward the behavior of delinquency because of the psychosocial control equal to $0,091(9,1 \%)$

\subsubsection{SMA Muhammadiyah 1 Ponorogo}

- The amount of indirect environmental influence of adolescents on the behavior of delinquency due to the psychosocial control of 0.237 or $23.7 \%$ ) negative effect.

- The amount of indirect influence of adolescent toward the behavior of delinquency because of psychosocial control equal to $0,035(3,5 \%)$ negative influence

\subsubsection{MA Darul Istiqomah}

- The amount of indirect environmental influence of adolescents on the behavior of delinquency because of the psychosocial control of 1,039 (103,9\%), negative influence.

- The amount of indirect influence of adolescents internal to delinquency behavior due to psychosocial control is $0,099(9.9 \%)$, negative effect.

\subsection{Discussion}

The trend of adolescent delinquency behavior is because adolescence is a transitional period of changes from physical, biological, psychological, and social changes that require 
adolescents to cope with and overcome the challenges of change with psychological, emotional, and behavioral consequences.

The Islamic Education Institution in Ponorogo Regency is 586 institutions; it gives an illustration that most teenagers are in Islamic institutions. The influence of adolescent environment on delinquency tendency of 0191 (19.1\%) and internal teenagers of $0.179(17.9 \%)$ had a negative effect. The magnitude of indirect environmental influence of adolescents on the tendency of delinquent behavior mediated by psychosocial control is $0.214(21.4 \%)$ and the indirect effect of adolescent influence on the tendency of delinquency behavior due to the psychosocial control of 0.045 (4.5\%). This provides information that the juvenile environment has a strong influence on the tendency of adolescent delinquency behavior rather than the internal factor of adolescents. And psychosocial control has a strong influence as well. The stronger the environmental and self-function of adolescents as psychosocial control, the less the tendency of delinquency behavior and the less good temperament in adolescents.

Comparison between Islamic Education Institution (Muhammadiyah School, Ma'arif School, Arrisalah Pesantren and Darul Istiqomah Pesantren) in giving treatment to delinquency adolescent as follows:

- The direct influence of adolescent environment on teenage delinquency dominated by SMA Muhammadiyah 1 equal to $49,4 \%$, MA Darul Istiqomah equal to $12,5 \%$ from others. It provides information that the Islamic Educational Institution, which lacks the role of pesantren/boarding school, has sufficient direct influence on the delinquency of adolescents from the Islamic Education Institution that plays pesantren such as MA Pesantren Modern Arrisalah and MA Darul Istiqomah. Teenagers in pesantren in daily life with Islamic values, commitment to self-identity, ability to control themselves, a strong belief in the teachings of Islam, and actively involved with the rules of the institution. The rule forms a social bond for adolescents as a form of psychosocial control.

- Indirect environmental influence of adolescents on delinquency behavior mediated by psychosocial control by 30.4\% in MA Ma'arif Al-Mukarram, 26.7\% in MA Pondok Modern Arrisalah, and others. This provides information that the pesantren system forms a social bond as a psychosocial control. Strong social ties, forming a psychosocial control against the tendency of delinquency behavior, as in MA Darul Istiqomah have negative indirect influence and SMA I Muhammadiyah at school time.

Psychosocial control model in prevention and prevention of adolescent delinquency behavior tendency in Islamic education institution in Ponorogo Regency that is:

- Discipline, several ways, and approach applied in the framework of discipline enforcement in pesantren /boarding school that is: Socialization of discipline Sunna, Eradicate discipline violation with night attendance, Involving the organization of students in discipline enforcement, and Various rules of discipline

- At-targhib wa At-tarhib.

\section{Conclusion}

Comparison in four Islamic educational institutions in Ponorogo district illustrates that there is a direct and indirect influence on the tendency of delinquency adolescent behavior, despite differences and similarities between the institutions. Psychosocial control models in overcoming the tendency of adolescent delinquency behavior have different variations on the 
four institutions, but the similarity is the enforcement of discipline and the application of the concept of at-targhib wa at-tarhib.

\section{References}

[1] H. Puspitawati, Kenakalan Pelajar Dipengaruhi Oleh Sistem Sekolah dan Keluarga IPB. Bogor: Press, 2009.

[2] R. A. Webster, M. Hunter, and J. A. Keats, "Peer and parental influences on adolescents' substance use: A path analysis," Int. J. Addict., vol. 29, no. 5, pp. 647657, 1994.

[3] P. A. Cowan and E. M. Hetherington, Handbook of social skills training and research. New Jersey: Wiley-Interscience, 1985.

[4] M. Grossman and K. M. Rowat, "Parental relationships, coping strategies, received support, and well-being in adolescents of separated or divorced and married parents," Res. Nurs. Health, vol. 18, no. 3, pp. 249-261, Jun. 1995.

[5] S. J. Robin, "EO: Attitude and peer cross pressure: adolescent drug and alcohol use," $J$. Drug Educ., vol. 26, pp. 69-99, 1996.

[6] H. Puspitawati, Kenakalan Pelajar Dipengaruhi oleh Sistem Sekolah dan Keluarga. Bogor: IPB Press, 2009.

[7] P. E. et al Diane, Psikologi Perkembangan. Kencana, 2008.

[8] W. S. Jhon, Adolescence. Jakarta: Erlangga, 2007.

[9] A. Bandura, W. H. Freeman, and R. Lightsey, "Self-Efficacy: The Exercise of Control," J. Cogn. Psychother., vol. 13, no. 2, pp. 158-166, Jan. 1999.

[10] N. Abuddin, Pemikiran Para Tokoh Pendidikan Islam. Jakarta: PT Rineka Cipta, 2001.

[11] F. R. Aan, Kenakalan Remaja Di Kalangan Santri Putra Di Asrama Dipanegoro Pondok Pesantren Yayasan Ali Maksum Krapyak. Yogyakarta: UIN Sunan Kalijaga, 2009.

[12] Y. Renti, "Bimbingan dan Konseling terhadap Siswi Bermasalah di Madrasah Mu'allimaat Muhammadiyah Yogyakarta UIN Sunan Kalijaga," UIN Sunan Kalijaga, Yogyakarta, 2009.

[13] "Wawancara bersama Ustadz Senior Pondok Modern Gontor Ponorogo Jawa Timur Indonesia." 2016.

[14] Kementerian Agama, "Data Statistics Ministry of Religious Affairs Ponorogo." 2016.

[15] Wahid, Menggerakkan Tradisi Pesantren. Yogyakarta: LkiS, 2001.

[16] M. Qomar, Pesantren dari Transformasi Metodologi menuju Demokratisasi Institusi. Jakarta: Erlangga, 2007.

[17] Suyono, "Peran Pondok Pesantren dalam Mengatasi Kenakalan Remaja (Studi Kasus di Pondok Pesantren Al-Muayyad Surakarta)," Universitas Sebelas Maret, Malang, 2012.

[18] T. Hirschi, Causes of Delinquency. California: Press Berkeley, 1969.

[19] D. El-Idhami, Psikologi Perkembangan. Bandung: PT. Remaja Rosda Karya, 2009.

[20] D. C. Kimmel and I. B. Weiner, "Adolescence," in A Developmental Transition, New York: John Wiley \& SonsInc, 1995.

[21] R. M. Lerner and D. F. Hultsch, Human Development a Life Span Perspective. New York: McGraw-Hill Inc., 1983.

[22] E. B. Hurlock, Developmental Psychology-A life span approach. New York: McGrawHill Inc., 2006. 
[23] S. Azwar, Penyusunan Skala Psikologi. Yogyakarta: Pustaka Pelajar, 2009.

[24] B. F. Skinner, Science and Human Behavior. New York: Mac-Millan Company, 1953.

[25] A. Bandura, Principle of Behavior Modification. New York: Holt Rinehart \& Wirston Inc, 1969.

[26] K. Kartono, Patologi Sosial 2 Kenakalan Remaja. Jakarta: Rajagrafindo Persada, 2006.

[27] E. Durkheim, The Division of Labour in Society. New York: Free Press, 1964.

[28] S. W. Sarlito, Psikologi Remaja. Jakarta: PT RajaGrafindo Persada, 2008.

[29] T. Hirschi, Causes of Delinquency. Berkeley: Univercity of Californiav Press, 1969.

[30] I. Ghozali, Konsep Aplikasi dengan Program AMOS 16.0. Semarang: Badan Penerbit Undip, 2008.

[31] A. Mujib and Mudzakkir, Ilmu Pendidikan Islam. Jakarta: Kencana Prenada Media Group Jakarta, 2008.

[32] R. Jalaludin, Psikologi Islam PT Raja Grafindo. Jakarta: PT Raja Grafindo Persada, 2002.

[33] Tubbs and Moss, Communication Theories Paradigm \& Theory. New York: McGraghill, 2000.

[34] Dinas Pendidikan, "Data dari Dinas Pendidikan Kabupaten Ponorogo." 2016.

[1] H. Puspitawati, Kenakalan Pelajar Dipengaruhi Oleh Sistem Sekolah dan Keluarga $I P B$. Bogor: Press, 2009.

[2] R. A. Webster, M. Hunter, and J. A. Keats, "Peer and parental influences on adolescents' substance use: A path analysis," Int. J. Addict., vol. 29, no. 5, pp. 647657, 1994.

[3] P. A. Cowan and E. M. Hetherington, Handbook of social skills training and research. New Jersey: Wiley-Interscience, 1985.

[4] M. Grossman and K. M. Rowat, "Parental relationships, coping strategies, received support, and well-being in adolescents of separated or divorced and married parents," Res. Nurs. Health, vol. 18, no. 3, pp. 249-261, Jun. 1995.

[5] S. J. Robin, "EO: Attitude and peer cross pressure: adolescent drug and alcohol use," J. Drug Educ., vol. 26, pp. 69-99, 1996.

[6] H. Puspitawati, Kenakalan Pelajar Dipengaruhi oleh Sistem Sekolah dan Keluarga. Bogor: IPB Press, 2009.

[7] P. E. et al Diane, Psikologi Perkembangan. Kencana, 2008.

[8] W. S. Jhon, Adolescence. Jakarta: Erlangga, 2007.

[9] A. Bandura, W. H. Freeman, and R. Lightsey, "Self-Efficacy: The Exercise of Control," J. Cogn. Psychother., vol. 13, no. 2, pp. 158-166, Jan. 1999.

[10] N. Abuddin, Pemikiran Para Tokoh Pendidikan Islam. Jakarta: PT Rineka Cipta, 2001.

[11] F. R. Aan, Kenakalan Remaja Di Kalangan Santri Putra Di Asrama Dipanegoro Pondok Pesantren Yayasan Ali Maksum Krapyak. Yogyakarta: UIN Sunan Kalijaga, 2009.

[12] Y. Renti, "Bimbingan dan Konseling terhadap Siswi Bermasalah di Madrasah Mu'allimaat Muhammadiyah Yogyakarta UIN Sunan Kalijaga,” UIN Sunan Kalijaga, Yogyakarta, 2009.

[13] "Wawancara bersama Ustadz Senior Pondok Modern Gontor Ponorogo Jawa Timur Indonesia." 2016.

[14] Kementerian Agama, "Data Statistics Ministry of Religious Affairs Ponorogo.” 2016.

[15] Wahid, Menggerakkan Tradisi Pesantren. Yogyakarta: LkiS, 2001.

[16] M. Qomar, Pesantren dari Transformasi Metodologi menuju Demokratisasi Institusi. Jakarta: Erlangga, 2007. 
[17] Suyono, "Peran Pondok Pesantren dalam Mengatasi Kenakalan Remaja (Studi Kasus di Pondok Pesantren Al-Muayyad Surakarta)," Universitas Sebelas Maret, Malang, 2012.

[18] T. Hirschi, Causes of Delinquency. California: Press Berkeley, 1969.

[19] D. El-Idhami, Psikologi Perkembangan. Bandung: PT. Remaja Rosda Karya, 2009.

[20] D. C. Kimmel and I. B. Weiner, "Adolescence," in A Developmental Transition, New York: John Wiley \& SonsInc, 1995.

[21] R. M. Lerner and D. F. Hultsch, Human Development a Life Span Perspective. New York: McGraw-Hill Inc., 1983.

[22] E. B. Hurlock, Developmental Psychology-A life span approach. New York: McGrawHill Inc., 2006.

[23] S. Azwar, Penyusunan Skala Psikologi. Yogyakarta: Pustaka Pelajar, 2009.

[24] B. F. Skinner, Science and Human Behavior. New York: Mac-Millan Company, 1953.

[25] A. Bandura, Principle of Behavior Modification. New York: Holt Rinehart \& Wirston Inc, 1969.

[26] K. Kartono, Patologi Sosial 2 Kenakalan Remaja. Jakarta: Rajagrafindo Persada, 2006.

[27] E. Durkheim, The Division of Labour in Society. New York: Free Press, 1964.

[28] S. W. Sarlito, Psikologi Remaja. Jakarta: PT RajaGrafindo Persada, 2008.

[29] T. Hirschi, Causes of Delinquency. Berkeley: Univercity of Californiav Press, 1969.

[30] I. Ghozali, Konsep Aplikasi dengan Program AMOS 16.0. Semarang: Badan Penerbit Undip, 2008.

[31] A. Mujib and Mudzakkir, Ilmu Pendidikan Islam. Jakarta: Kencana Prenada Media Group Jakarta, 2008.

[32] R. Jalaludin, Psikologi Islam PT Raja Grafindo. Jakarta: PT Raja Grafindo Persada, 2002.

[33] Tubbs and Moss, Communication Theories Paradigm \& Theory. New York: McGraghill, 2000.

[34] Dinas Pendidikan, "Data dari Dinas Pendidikan Kabupaten Ponorogo.” 2016. 